\title{
Fungal Diseases of Strawberry
}

\author{
Albert O. Paulus \\ Plant Pathology Department, University of California, Riverside, CA 92521
}

Fungal diseases of strawberry are important worldwide and occur in all parts of the plant, including flowers, fruit, leaves, crowns, and roots. Yields and quality of fruit are usually reduced when strawberry plants are infected by fungi. The ensuing discussion will focus on those fungal diseases important in California strawberry nursery and production areas.

\section{Botrytis gray mold rot}

Botrytis gray mold rot, caused by Botrytis cinerea Pers. ex Fr., is an important fruit rot wherever strawberries are grown. The fungus usually produces a velvety gray growth on the surface of the fruit, but, in high humidity, the surface growth may be cottony and white, with little or no spore production. Mycelium of the fungus is present in senescent petals, stamens, and calyces of marketable fruit (Powelson, 1960). In Ontario, Canada, 90\% to 99\% of the inoculum (conidia) was produced from mycelium in the laminae and petioles of dead strawberry leaves (Braun and Sutton, 1987).

Humidity is the most important factor regulating the occurence of gray mold. Frequent rains induce maximum disease incidence. The optimum field conditions for the development of the disease are an environment at 15 to $20 \mathrm{C}$ with $>90 \%$ relative humidity (Devaux, 1978). Furthermore, it seems that these conditions must be maintained for more than $28 \mathrm{hr}$ for an epidemic development of the disease. In Ohio, optimum temperature for flower infection was $20 \mathrm{C}$, with $100 \%$ infection-caused by $24 \mathrm{hr}$ of wetness (Bulger et al., 1987). For inoculation of flowers at 20C, the highest incidence of fruit infection $(60 \%)$ was recorded after $32 \mathrm{hr}$ of wetness. Flower and fruit infection was greatly reduced above $25 \mathrm{C}$ and below $15 \mathrm{C}$ for all wetness durations.

Protective fungicidal sprays are helpful for the control of gray mold fruit rot during periods of moderate disease incidence. During periods of continuous rainfall, however, control of the disease is almost impossible. Captan or thiram was effective for control in trials in Louisiana (Horn, 1961). Benomyl or thiophanate-methyl fungicides were effective for control during the late 1960s and early 1970s (Paulus et al., 1969; Gourley, 1974).

Excellent control in California was obtained with vinclozolin or captan + benomyl, but the vinclozolin treatment was most effective for the reduction of the fruit rot (Paulus et al., 1978). Captan or thiram provided intermediate control. Vinclozolin alone and in combination with other fungicides such as captan consistently provided excellent gray mold control in Ohio trials (Ellis et al., 1987). Excellent control has been obtained with chlorothalonil, captafol, and dichlofluanid outside the United States, but these fungicides have never been- registered by the EPA for use in commercial strawberry production fields (Peterson, 1973; Aharoni and Barkai-Golan, 1987).

Repeated use of the benzimidazole and dicarboximide fungicides caused the development of isolates of $B$. cinerea resistant to the fungicides. Isolates of $B$. cinerea from slow-developing lesions on strawberries from plants treated with iprodione or vinclozolin fungicides grew on potato dextrose agar containing 10,000 ppm iprodione or $1000 \mathrm{pm}$ vinclozolin. When isolates sensitive to iprodione and vinclozolin were placed on PDA containing between 1 and 5 ppm of one of these fungicides, a few of the cultures showed mycelial growth after incubation for 7 days (Dennis and Davis, 1979). During-the 1978 California strawberry season, benomyl used alone was not effective for the control of $B$. cinerea. In tunnel experiments, the efficacy of dicarboximide sprays in controlling gray mold of strawberries was greatly decreased by the presence of dicarboximide-resistant forms of B. cinerea (Hunter et al., 1987). Alternative "partner" fungicides (thiram, chlorothalonil) delayed build-up of resistance to dicarboximides.

'Plant Pathologist.
Postharvest rot caused by B. cinerea and other fungi is particularly serious because losses may include the fruit, accumulated costs of harvesting, packaging, cooling, and transportation; also, markets may be depressed as a result of consumer dissatisfaction. Gray mold fruit rot is held in check at $5 \mathrm{C}$ or below or a combination of $10 \%$ to $15 \% \mathrm{CO}_{2}$ in the atmosphere; $10 \mathrm{C}$ or below is effective for good market arrivals (Sommer et al., 1973). California strawberries stored in atmospheres containing $20 \%$ or $30 \% \mathrm{CO}_{2}$ developed persistent off-flavors (Harris and Harvey, 1973). Field sprays with iprodione, metameclan, or captafol applied once weekly during flowering and fruit development resulted in a significant reduction in $B$. cinerea decay in 'Aliso' strawberries during 10 days of storage at $2 \mathrm{C}$ and a subsequent 2 days of shelf life (20C) to simulate ocean transport followed by marketing. Wrapping freshly hatvested strawberries, harvested from unsprayed plots, in sealed PVC wraps resulted in better maintenance of fruit firmness, less weight loss, delayed drying of the calyx, and a significant reduction in the incidence of botrytis decay. The improvement in the storability of the fruit coincided with the formation of $\mathrm{CO}$,-enriched atmosphere within the wraps. The PVC film responsible for the accumulation of the highest level of $\mathrm{CO},(10.5 \%)$ was the most effective in controlling botrytis decay during storage. Combining preharvest fungicidal sprays of iprodione with the most-suitable PVC wrap considerably increased the decay control achieved by the wrapping procedure alone (Aharoni and Barkai-Golan, 1987). California strawberries uniformly cooled to $2 \mathrm{C}$ before truck shipment were at an average of $7 \mathrm{C}$ on arrival at U.S. East Coast markets when pallets were placed against the sidewalls and a lengthwise channel was left along the centerline of the truck. Average arrival temperature was $5 \mathrm{C}$ when the pallets were placed away from the sidewalls and adjacent to one another along the centerline. Strawberries shipped in pallets with average CO, levels $>10 \%$ had about one-half as much decay as berries shipped in normal air (Harvey et al., 1980).

It is generally agreed among horticulturists and plant pathologists that no real resistance to gray mold is known among strawberry cultivars. Field observations, however, confirm that cultivars differ in their susceptibility to gray mold. Cultivars with less-dense leaf growth, fruit produced outside the canopy, and firm fruit may develop less gray mold fruit rot than their opposites (Daubeny and Pepin, 1977; Maas, 1978; Barritt, 1980).

\section{Strawberry leafspot}

Strawberry leafspot, caused by Ramularia tulasnei Sacc. (sexual stage Mycosphaerella fragariae Tul.), is a common disease of strawberry. The disease is less serious today than it used to be because plant breeders have incorporated resistance into some current cultivars. In California, 'Pajaro' and 'Chandler' are susceptible, whereas 'Selva' is more tolerant of leafspot in growers' fields.

The disease is first noticed as small, purplish circular spots on the surface of young leaflets. As the lesion enlarges, the center of the spot becomes gray to white and is surrounded by distinct reddish-brown borders. The leaf spot fungus may also attack leaf stems, fruit stalks, and fruit calyces, all of which exhibit infected spots similar to those described for leaves. On the stems and stalks, however, the lesions are more elongated than circular. Infection of strawberry fruit is not common. Usually, one to several seeds on the berry, including the areas surrounding them, are brownish-black. The pulp of the berry under these infected areas is discolored. These lesions lower the grade or render the fruit unmarketable (Fulton, 1958).

Where strawberries are grown in the spring and summer, the fungus produces sclerotia and perithecia as dormant overwintering structures. Only conidia are produced in the United States. In California, tiny black sclerotia have been found on infected stolons and 
petioles of strawberry plants after storage at $-2 \mathrm{C}$. When these infected plants were planted in production-fields, they were the first to show leafspot symptoms in early December. R. tulasnei survived for 7 months when sclerotia-colonized plant debris was buried in the field (Lile et al., 1989).

Common leafspot is favored by prolonged wet periods and low temperatures in winter and spring in California. Leafspot caused unusually severe damage in many commercial strawberry plantings in Arkansas during the first week of May in 1957. Continued and above-average rainfall during April apparently was the main factor responsible for the leafspot epiphytotic. Rainfall at Fayetteville was $287 \mathrm{~mm}$ for April, while normal rainfall is $119 \mathrm{~mm}$ (Dale and Fulton, 1957). Severe leafspot disease also developed in 1957 in the Benton Harbor, Mich., strawberry area. In Apr. 1956, the area received 12 days of precipitation and $128 \mathrm{~mm}$ of rainfall, whereas in Apr. 1957, there were 21 days of precipitation and $144 \mathrm{~mm}$ of rainfall (Fulton, 1958). The optimum temperature for conidia production and germination of the fungus is between 13 and 21C (Fall, 1951; Plakidas, 1931). However, a lower temperature delays the maturity of young leaflets, thus extending their susceptible period.

The resistance of strawberry cultivars to the leaf spot fungus varies in the field, and resistant cultivars have been used to indicate that races of the pathogen exist. In Louisiana, cultivars were grouped into three general classes: I, Resistant in the field and to infection by artificial inoculation; II, resistant in the field but highly susceptible when experimentally inoculated; and III, susceptible in the field and to infection after experimental inoculation (Plakidas, 1948). Four provisional races of the fungus were noted in southern Illinois (Nemec, 1971). Six virulence groups of Mycosphaerella fragariae (Tul.) Lindau were noted on nine strawberry cultivars in Ontario (Bolton, 1962).

Control of early season infections of Ramularia was achieved in California by the use of benomyl or thiophanate-methyl fungicide dips to strawberry nursery plants before planting (Paulus et al., 1973). After several years of use, it became apparent that the effectiveness of benomyl or thiophanate-methyl had begun to decrease. Chlorothalonil as a plant dip or foliar spray was effective for the control of Ramularia leafspot. A hot water dip of $3 \mathrm{~min}$ at $52 \mathrm{C}$ killed the sclerotia and had no detrimental effect on strawberry plants. Because of the problem of dipping large numbers of strawberry plants in hot water, it is debatable whether the procedure will ever-be adopted commercially. Soil fumigation with methyl bromide-chloropicrin or basamid provided complete control of buried sclerotia (Lile et al., 1989).

\section{Anthracnose}

Strawberry anthracnose was observed in strawberry runners in Florida (Brooks, 1931) in 1926-29, and, by 1930, the disease was fairly well-scattered throughout central Florida. The causal organism was named Colletottichum fragariae Brooks. Later, other fungi were identified as causing anthracnose: $C$. dematium (Pers:Fr) Grove, C. acutatum Simmonds, and C. gloeosporioides Penz. (Maas, 1980). The effects of $C$. acutatum and $C$. fragariae on strawberry plants and fruit are now noted. Anthracnose fruit rot is characterized by dark brown, circular, sunken, firm rot lesions that usually turn black after a few days. The lesions occur anywhere on the ripe fruit. Two or more lesions may coalesce, and are occasionally covered by masses of buff-colored spores (Howard, 1972). Crown-infected plants are characterized by a sudden wilting of the plants. Crown infections first appear as gray to black streaks in the vascular tissue, whereas a pocket of cinnamon brown tissue develops in advanced infections (Horn, 1963; Gubler, 1988). Anthracnose may cause dark lesions on flower stalks, runners, petioles, and leaves. Infections on runners and petioles first appear as small, lenticular, black, sunken lesions. Lesions may expand to where they girdle the runner or petiole, causing a collapse of distal tissues.

On infected leaves, flower stalks, and fruit, the fungus produces fruiting structures (acervuli), and numerous spores are borne in a mucilaginous matrix. Spores are spread by rain and, possibly, by insects.

In California, propagules of $C$. acutatum were detected in the soil of a recently fallowed strawberry plot. A survey of strawberry nursery and production fields showed that the fungus was present in soils from sites with recent histories of strawberry anthracnose. C. acutatum from naturally infested soil initiated disease in strawberry plants in the greenhouse. The fungus was able to survive in buried strawberry tissue for 9 months (Eastburn and Gubler, 1990). Colletotrichum fragariae attacks Cassia obtusifolia in Florida and may be a principal source of primary inoculum there (Howard and Albregts, 1973). Blue lupine (Lupinus angustifolius L.) was susceptible, in greenhouse inoculations, to isolates of $C$. frageriae obtained from North Carolina, Louisiana, and Florida (Welty, 1984).

Warm (>21C), wet conditions during flowering and fruiting favor the disease, but do not favor strawberry production. Anthracnose has caused extensive losses in Florida and California after rainy periods in March or April (Howard, 1972; Wilhelm; 1984).

The primary inoculum of $C$. acutatum is carried on planting stock harvested from fields where the disease has occurred. The fungus was isolated from crown tissue and from soil adhering to crowns of planting stock in storage.

Control of the disease is difficult in nursery and commercial production fields. Planting stock obtained from nurseries known to be free of the anthracnose fungus gave complete control of the disease in commercial fields under California conditions. Colletotrichum acutatum was never recovered from soil, infected runners, or crowns that had been fumigated with methyl bromide-chloropicrin (Gubler et al., 1988). Benomyl plus captan or dichlofluanid gave good control of anthracnose in New Zealand trials (Cheah and Soteros, 1984). Unfortunately, dichlofluanid has never been registered for use in the United States. Newer, more-effective fungicides are needed for adequate control of anthracnose fruit rot.

Strawberry cultivars vary in their susceptibility to the anthracnose fungus. Many California cultivars are very susceptible to anthracnose, but 'Sequoia' is resistant. Breeding for resistance to strawberry anthracnose is a major factor in the development of new strawberry cultivars in the southeastern part of the United States. Cultivars such as 'Florida Belle' and 'Dover', though not immune, have resistance adequate for control in normal winter and spring seasons (Delp, 1981). A new cultivar, FL 79-1126, is highly resistant to anthracnose; very firm, but the fruit has a tendency to form cracks at the shoulder (Chandler et al., 1988). Strawberry resistance to $C$. fragariae is influenced by environmental conditions after inoculation. Plants incubated at a high temperature (35C) for $48 \mathrm{hr}$ in a dew chamber $(\approx 100 \% \mathrm{RH})$ had higher disease severity ratings than comparable plants incubated at 25 or $30 \mathrm{C}$ (Smith and Black, 1987). Although high inoculum density, long wet periods, and high temperatures can lower the resistance of a plant to strawberry anthracnose, disease development is always retarded on resistant cultivars compared with susceptible cultivars.

\section{Powdery mildew}

Powdery mildew of strawberry, caused by Sphaerotheca macularis (Wallr. ex Fr.) Jacz. f. sp. fragariae, has been reported from most areas of the world where strawberries are grown. In southern California, powdery mildew usually is not important until around 1 May, when the weather warms and some strawberries are sent to the processing market. In northern California, the disease is present in dry, cool, foggy months of the summer and fall.

Leaves, calyces of flowers, and fruit support growth of the mildew. A white powdery growth develops on the underside of the leaves. Infected leaves cup upward, become reddish on the underside and, in severe instances, develop areas that appear badly burned at the margins. Reddening of infected fruit is delayed, and, in severe instances, fruit shows a white powdery surface film (Wilhelm, 1961).

The fungus survives from season to season as mycelium in old plants. Chains of conidia are produced in the spring and summer, when weather conditions are favorable. The conidia are air-borne and are deposited close to the source of inoculum. The germination of conidia on the host leaves is satisfactory between 15 and $25 \mathrm{C}$, but maximum germination is obtained at 20C. Whereas conidia of $S$. macularis f. sp. fragariae can germinate at $80 \% \mathrm{RH}$ on host leaves, they germinate best at $100 \%$ RH. Free water has a lethal 
petioles of strawberry plants after storage at $-2 \mathrm{C}$. When these infected plants were planted in production-fields, they were the first to show leafspot symptoms in early December. R. tulasnei survived for 7 months when sclerotia-colonized plant debris was buried in the field (Lile et al., 1989).

Common leafspot is favored by prolonged wet periods and low temperatures in winter and spring in California. Leafspot caused unusually severe damage in many commercial strawberry plantings in Arkansas during the first week of May in 1957. Continued and above-average rainfall during April apparently was the main factor responsible for the leafspot epiphytotic. Rainfall at Fayetteville was $287 \mathrm{~mm}$ for April, while normal rainfall is $119 \mathrm{~mm}$ (Dale and Fulton, 1957). Severe leafspot disease also developed in 1957 in the Benton Harbor, Mich., strawberry area. In Apr. 1956, the area received 12 days of precipitation and $128 \mathrm{~mm}$ of rainfall, whereas in Apr. 1957, there were 21 days of precipitation and $144 \mathrm{~mm}$ of rainfall (Fulton, 1958). The optimum temperature for conidia production and germination of the fungus is between 13 and 21C (Fall, 1951; Plakidas, 1931). However, a lower temperature delays the maturity of young leaflets, thus extending their susceptible period.

The resistance of strawberry cultivars to the leaf spot fungus varies in the field, and resistant cultivars have been used to indicate that races of the pathogen exist. In Louisiana, cultivars were grouped into three general classes: I, Resistant in the field and to infection by artificial inoculation; II, resistant in the field but highly susceptible when experimentally inoculated; and III, susceptible in the field and to infection after experimental inoculation (Plakidas, 1948). Four provisional races of the fungus were noted in southern Illinois (Nemec, 1971). Six virulence groups of Mycosphaerella fragariae (Tul.) Lindau were noted on nine strawberry cultivars in Ontario (Bolton, 1962).

Control of early season infections of Ramularia was achieved in California by the use of benomyl or thiophanate-methyl fungicide dips to strawberry nursery plants before planting (Paulus et al., 1973). After several years of use, it became apparent that the effectiveness of benomyl or thiophanate-methyl had begun to decrease. Chlorothalonil as a plant dip or foliar spray was effective for the control of Ramularia leafspot. A hot water dip of $3 \mathrm{~min}$ at $52 \mathrm{C}$ killed the sclerotia and had no detrimental effect on strawberry plants. Because of the problem of dipping large numbers of strawberry plants in hot water, it is debatable whether the procedure will ever-be adopted commercially. Soil fumigation with methyl bromide-chloropicrin or basamid provided complete control of buried sclerotia (Lile et al., 1989).

\section{Anthracnose}

Strawberry anthracnose was observed in strawberry runners in Florida (Brooks, 1931) in 1926-29, and, by 1930, the disease was fairly well-scattered throughout central Florida. The causal organism was named Colletottichum fragariae Brooks. Later, other fungi were identified as causing anthracnose: $C$. dematium (Pers:Fr) Grove, C. acutatum Simmonds, and C. gloeosporioides Penz. (Maas, 1980). The effects of $C$. acutatum and $C$. fragariae on strawberry plants and fruit are now noted. Anthracnose fruit rot is characterized by dark brown, circular, sunken, firm rot lesions that usually turn black after a few days. The lesions occur anywhere on the ripe fruit. Two or more lesions may coalesce, and are occasionally covered by masses of buff-colored spores (Howard, 1972). Crown-infected plants are characterized by a sudden wilting of the plants. Crown infections first appear as gray to black streaks in the vascular tissue, whereas a pocket of cinnamon brown tissue develops in advanced infections (Horn, 1963; Gubler, 1988). Anthracnose may cause dark lesions on flower stalks, runners, petioles, and leaves. Infections on runners and petioles first appear as small, lenticular, black, sunken lesions. Lesions may expand to where they girdle the runner or petiole, causing a collapse of distal tissues.

On infected leaves, flower stalks, and fruit, the fungus produces fruiting structures (acervuli), and numerous spores are borne in a mucilaginous matrix. Spores are spread by rain and, possibly, by insects.

In California, propagules of $C$. acutatum were detected in the soil of a recently fallowed strawberry plot. A survey of strawberry nursery and production fields showed that the fungus was present in soils from sites with recent histories of strawberry anthracnose. C. acutatum from naturally infested soil initiated disease in strawberry plants in the greenhouse. The fungus was able to survive in buried strawberry tissue for 9 months (Eastburn and Gubler, 1990). Colletotrichum fragariae attacks Cassia obtusifolia in Florida and may be a principal source of primary inoculum there (Howard and Albregts, 1973). Blue lupine (Lupinus angustifolius L.) was susceptible, in greenhouse inoculations, to isolates of $C$. frageriae obtained from North Carolina, Louisiana, and Florida (Welty, 1984).

Warm (>21C), wet conditions during flowering and fruiting favor the disease, but do not favor strawberry production. Anthracnose has caused extensive losses in Florida and California after rainy periods in March or April (Howard, 1972; Wilhelm; 1984).

The primary inoculum of $C$. acutatum is carried on planting stock harvested from fields where the disease has occurred. The fungus was isolated from crown tissue and from soil adhering to crowns of planting stock in storage.

Control of the disease is difficult in nursery and commercial production fields. Planting stock obtained from nurseries known to be free of the anthracnose fungus gave complete control of the disease in commercial fields under California conditions. Colletotrichum acutatum was never recovered from soil, infected runners, or crowns that had been fumigated with methyl bromide-chloropicrin (Gubler et al., 1988). Benomyl plus captan or dichlofluanid gave good control of anthracnose in New Zealand trials (Cheah and Soteros, 1984). Unfortunately, dichlofluanid has never been registered for use in the United States. Newer, more-effective fungicides are needed for adequate control of anthracnose fruit rot.

Strawberry cultivars vary in their susceptibility to the anthracnose fungus. Many California cultivars are very susceptible to anthracnose, but 'Sequoia' is resistant. Breeding for resistance to strawberry anthracnose is a major factor in the development of new strawberry cultivars in the southeastern part of the United States. Cultivars such as 'Florida Belle' and 'Dover', though not immune, have resistance adequate for control in normal winter and spring seasons (Delp, 1981). A new cultivar, FL 79-1126, is highly resistant to anthracnose; very firm, but the fruit has a tendency to form cracks at the shoulder (Chandler et al., 1988). Strawberry resistance to $C$. fragariae is influenced by environmental conditions after inoculation. Plants incubated at a high temperature (35C) for $48 \mathrm{hr}$ in a dew chamber $(\approx 100 \% \mathrm{RH})$ had higher disease severity ratings than comparable plants incubated at 25 or $30 \mathrm{C}$ (Smith and Black, 1987). Although high inoculum density, long wet periods, and high temperatures can lower the resistance of a plant to strawberry anthracnose, disease development is always retarded on resistant cultivars compared with susceptible cultivars.

\section{Powdery mildew}

Powdery mildew of strawberry, caused by Sphaerotheca macularis (Wallr. ex Fr.) Jacz. f. sp. fragariae, has been reported from most areas of the world where strawberries are grown. In southern California, powdery mildew usually is not important until around 1 May, when the weather warms and some strawberries are sent to the processing market. In northern California, the disease is present in dry, cool, foggy months of the summer and fall.

Leaves, calyces of flowers, and fruit support growth of the mildew. A white powdery growth develops on the underside of the leaves. Infected leaves cup upward, become reddish on the underside and, in severe instances, develop areas that appear badly burned at the margins. Reddening of infected fruit is delayed, and, in severe instances, fruit shows a white powdery surface film (Wilhelm, 1961).

The fungus survives from season to season as mycelium in old plants. Chains of conidia are produced in the spring and summer, when weather conditions are favorable. The conidia are air-borne and are deposited close to the source of inoculum. The germination of conidia on the host leaves is satisfactory between 15 and $25 \mathrm{C}$, but maximum germination is obtained at 20C. Whereas conidia of $S$. macularis f. sp. fragariae can germinate at $80 \% \mathrm{RH}$ on host leaves, they germinate best at $100 \%$ RH. Free water has a lethal 
effect on conidia, and rain has a drastic deleterious effect on spore dispersal (Peries, 1962; Jhooty and McKeen, 1965). Cleistothecia were found in Florida in 1981 on transplants that had been grown in Maine and Michigan (Howard and Albregts, 1982). Because the cleistothecial stage is only occasionally found, it is not considered a primary inoculum source.

Sulfur or benomyl fungicides have been used for control of powdery mildew of strawberry. Sulfur must be used with caution in the warmer production areas because it may cause burning of foliage above 27C. Repeated use of benomyl in former years and the development of resistant strains of the parasite may reduce the effectiveness of this fungicide.

Strawberry cultivars vary widely in their susceptibility and tolerance to' powdery mildew. Plant breeders continue to evaluate breeding lines (Gooding et al., 1981; Simpson, 1987).

\section{Red stele}

Red stele, caused by Phytophthora fragariae Hickman, is a serious economic disease in almost any area with wet winters and with soils having poor internal drainage. The disease was first observed in the Lanarkshire district of Scotland in 1920; the first published report of the occurrence of the disease in the United States was from Illinois in 1935 (Bain and Demaree, 1945).

Above-ground symptoms are severe dwarfing and death of plants in the lower, poorly drained parts of fields. Individual plants appear to decrease in size as the older leaves wilt, dry up, and are replaced by smaller new leaves borne on shortened petioles. On warm, dry days in early spring, there may be a sudden wilting of entire plants or of the outer leaves only. Severely infected plants bear little or no fruit, and any fruit formed is of inferior quality.

Young lateral roots are often completely rotted by the pathogen, and the new crown roots die from the tips back. The dying from the tips of the new crown roots gives rise to a symptom called "rattail". Cutting these rat-tail-like roots lengthwise above the dead tips usually discloses the red stele of the root (Bain and Demaree, 1945; Wilhelm, 1961).

Maximum infection by $P$. fragariae occurs under conditions that promote the liberation of zoospores. These conditions are heavy rainfall, frequent irrigations, or waterlogging from below. Oospores enable the fungus to survive for long periods in the soil, after which they germinate to produce sporangia. In North Carolina, oospores were detected in infected strawberry roots from January through May in 1985 and 1986, with- the maximum number having been observed in March. The sporangia germinate indirectly to produce many zoospores. The optimum temperature range for both zoospore germination on host roots and oospore development in host tissue was 15 to $20 \mathrm{C}$. Chemicals exuded from the root tips attract the zoospores. The zoospores encyst in large numbers on the roots, produce germ tubes, and penetrate the epidermis. Within 3 days, the infecting fungus reaches the differentiating phloem and pericycle (Hickman and English, 1951; Goode, 1956; George and Milholland, 1986b, 1987a).

At least 10 physiological races of $P$. fragariae have been reported in the United States, and 15 races have been determined worldwide. Because no uniform system for testing exists, it may be that some of the races are similar to those already reported (Converse et al., 1958; Pepin and Daubeny, 1964; Maas, 1984).

Fumigation with methyl bromide and chloropicrin, which is normally used for the control of verticillium wilt and black root rot, is effective in reducing the inoculum potential of $P$. fragarie in the soil (Jeffers, 1957). The fungus can be carried on infected nursery stock, and growers should therefore obtain nursery plants from nurserieswith. a clean stock program. Fungicidal drenches with the systemic fungicide metalaxyl significantly controlled red stele in Connecticut, and plants treated with metalaxyl the 2nd year after transplanting produced an average of $161 \%$ more total fruit by weight than did untreated plants (McIntrye and Walton, 1981). Red stele disease is more severe in acidic soils and lime should be added to increase the $\mathrm{pH}$ to above 7.0. Planting nursery plants on high beds and careful water management, along with soil fumigation, has alleviated the effects of red stele in California. Growers should select resistant cultivars wherever possible, but, with numerous physiological races of the fungus found in nature, it becomes a difficult problem to maintain resistance (Anderson and Colby, 1942).

\section{Crown rot and leather fruit rot}

Crown rot (vascular collapse) and leather fruit rot are caused by Phytophthora cactorum (Leb. \& Cohn) Schroet, and occur sporadically in California. Different strains of the fungus cause the different diseases. Crown rot is characterized by an intensive browning and eventual disintegration of the vascular tissues of the crown. Plants wilt and collapse. Suggestions have been made that infection can occur after penetration through roots, petiole bases, and runner tips (Wilhelm and Nelson, 1980).

The leather-rot strains of the fungus can infect fruit at any stage of development. On green fruit, diseased areas are dark brown or green and have brown margins. As the rot spreads, the entire fruit becomes brown, and its rough texture makes it appear leathery. Occasionally, under conditions of high moisture, a fine white moldy growth appears on the fruit surface. Eventually, both infected green and mature fruit dry down to form hard, shriveled-mummies.

The leather fruit rot fungus survives from season to season as oospores on mummified fruit; oospores remain viable in the soil for even longer. Oospores germinate in the spring to produce sporangia. Sporangia can be found on infected fruit after $3 \mathrm{hr}$ of wetness between 15 and $25 \mathrm{C}$ and 100 or more sporangia per fruit can be produced at these temperatures with $16 \mathrm{hr}$ of wetness. Between 17 and $25 \mathrm{C}, 1 \mathrm{hr}$ of wetness resulted in $80 \%$ infection of strawberry fruit (Grove et al., 1985a, 1985b, 1985c, 1985d).

Strawberry production fields should have excellent internal soil drainage and air circulation. Polyethylene or straw mulches reduce fruit contact with the soil. Because leather rot and gray mold are commonly found in the same fields, it is usually necessary to use a combination of two fungicides for control. Captan, thiram, or folpet have been standard fungicides for the control of leather rot, whereas vinclozolin, benomyl, or thiophanate methyl has been effective for gray mold. Metalaxyl is very effective against the leather rot fungus, but may not be registered in all areas of the world where this disease is an economic problem (Tanboon-Ek, 1983; Grove et al., 1985).

\section{Verticillium wilt}

Verticillium wilt, caused by Verticillium dahliae Kleb., occurs throughout the temperate zones of the world wherever strawberries are grown. Verticillium wilt caused devastating losses in California strawberry fields until the development of chloropicrin and methyl bromide soil fumigation as a standard practice in the early 1960s.

Verticillium wilt causes a collapse of strawberry plants during the peak of the first year's growth. Outer leaves of the plants wilt and collapse in the late spring. Growth of new leaves is retarded and the plant is stunted. There is usually no vascular discoloration visible in the crown.

Microsclerotia of $V$. dahliae enable the fungus to survive in the soil for many years and therefore rotation is ineffective for control. The fungus also has a wide host range that includes tomato, potato, chrysanthemum, and various weeds, such as Solanum sarachoides Sendt.

Effective control of verticillium wilt was first achieved by Wilhelm and Koch, who applied $218 \mathrm{~kg}$ of chloropicrin by handgun in Fall 1953 to 0.4 ha $(480 \mathrm{lb} / \mathrm{acre})$ of land. On this fumigated land, 'Shasta' strawberries produced the first- and second-year yields of 24.2 and $41.2 \mathrm{t} \cdot \mathrm{ha}^{-1}$, respectively. These were in constrast to normal yields of 9.8 and $18.7 \mathrm{t} \cdot \mathrm{ha}^{-1}$ in the same field on land fumigated with ethylene dibromide. A successful trial of machine application of chloropicrin followed in 1955. During 1957 and 1958, the idea of mixing chloropicrin and methyl bromide was conceived and tested. The first experimental results, reported in 1961, indicated that methyl bromide not only augmented the fungicidal properties of chloropicrin, but also gave excellent weed control. The fumigant mixture required immediate covering of the fumigated soil with polyethylene film. With the first applications of the mixture, it was only possible to fumigate $50 \%$ of the field because it was necessary to cover both 
sides of the polyethylene tarpaulin with soil to hold it in place. About $48 \mathrm{hr}$ after fumigation, the tarpaulin was taken up from the fumigated area of the field so the alternate strips of non-fumigated soil could be treated. Later, a glue was sprayed on the top of one side of the tarpaulin to complete a gas seal and soil was applied to the opposite side. This permitted the fumigation of the entire field in one operation. The personnel in California who were the driving forces in the development of machine application of methyl bromide-chloropicrin soil fumigants were Steven Wilhelm, Plant Pathology Dept., Univ. of California, Berkeley; Richard Storkan, Neil A. Maclean Co., Belmont, Calif. (subsequently formed Tri-Cal with Jerry Hanes and Robert McCaslin) and Harold Lembright, Dow Chemical Company. Soil fumigation of strawberry fields in California in 1989 is still as effective for increasing yield as it was when first developed in the early 1960s. Some fields have been fumigated and replanted with strawberries 15 times without a buildup of toxic residues or destruction of desirable soil microflora (Johnson et al., 1962; Wilhelm and Paulus, 1980).

\section{Black root rot}

Black root rot is a complex disease characterized by feeder rootlet killing, deterioration and blackening of the main root systcm, and decline in vigor and productivity of the plants. A number of fungi such as Ceratobasidium sp. (Rhizoctonia fragariae Husain and McKeen), Idriella lunata Nelson et Wilhelm, Pythium ultimum Trow, $P$. irregulare Buis, and various other Pythium spp., Pyrenochaeta spp., Cylindrocarpon destructans, and Fusarium spp., have been reported to be involved in the black root rot disease.

The disease is generally associated with soils that have a high clay content. Freezing or waterlogging of the soil and consequent lack of oxygen in the soil may contribute to the problem.

Soil fumigation with methyl bromide-chloropicrin controls many of the fungi involved in the black root rot disease, but reinvasion by fast growing fungi such as Pythium or Rhizoctonia may reduce the effects of fumigation later on in the growing season (Nelson, 1957; Wilhelm, 1961; Drozdowski, 1987; Schroth, 1988).

\section{Literature Cited}

Aharoni, Y. and R. Barkai-Golan. 1987. Pre-harvest fungicide sprays and polyvinyl wraps to control Botrytis rot and prolong the post-harvest storage life in strawberries. J. Hort. Sci. 62:177-181.

Anderson, H.W. and A.S. Colby. 1942. Red stele of strawberry on Pathfinder and Aberdeen. Plant Dis. Rptr. 26:291-292.

Bain, H.F. and J.B. Demaree. 1945: Red stele root disease of the strawberry caused by Phytophthora fragariae. J. Agr. Res. 70:11-30.

Barritt, B.H. 1980. Resistance of strawberry clones to Botrytis fruit rot. J. Amer. Soc. Hort. Sci. 105:160-164.

Bolton, A.T. 1962. Pathogenic variation in Mycosphaerella fragariae. Can. J. Bot. 40:647-650.

Braun, P.G. and J.C. Sutton. 1987. Inoculum sources of Botrytis cinerea in fruit rot of strawberries in Ontario. Can. J. Plant. Pathol. 9:1-5.

Brooks, A.N. 1931. Anthracnose of strawberry caused by Colletotrichum fragariae, N. Sp. Phytopathology 21:739-744.

Bulger, M.A., M.A. Ellis, and L.V. Madden. 1987. Influence of temperature and wetness duration on infection of strawberry flowers by Botrytis cinerea and disease incidence of fruit originating from infected flowers. Phytopathology 77:1225-1230.

Chandler, C.K., E.E. Albregts, and C.M. Howard. 1988. Evaluation of strawberry cultivars and advanced selections at Dover, Florida, 1986-88. Adv. Strawberry Prod. 8:19-22.

Cheah, L.H. and J.J. Soteros. 1984. Control of black fruit rot of strawberry. Proc. 37th N.Z. Weed \& Pest Control Conf. 37:160-162.

Converse, R.H., D.H. Scott, and G.F. Waldo. 1958. Two additional races of Phytophthora fragariae Hickman in Maryland. Plant Dis. Rptr. 42:837840.

Corke, A.T.K. and V.W.L. Jordan. 1978. Powdery mildews of bush and soft fruits, p. 347-358. In: D.M. Spencer (ed.). The powdery mildews. Academic, London.

Dale, J.L. and J.P. Fulton. 1957. Severe loss from strawberry leaf spot in Arkansas in 1957. Plant Dis. Rptr. 41:681-682.

Daubeny, H.A. and H.S. Pepin. 1977. Evaluation of strawberry clones for fruit rot resistance. J. Amer. Soc. Hort. Sci. 102:431-435.

Dennis, C. and R.P. Davis. 1979. Tolerance of Botrytis cinerea to iprodione and vinclozolin. Plant Pathol. 28:131-133.
Devaux, A. 1978. Etude epidemiologique de la moississure grise des fraises et essais de lutte. Phytoprotection 59:19-27.

Drodzdowski, J. 1987. A survey of fungi associated with strawberry black root rot in commercial fields. Adv. Strawberry Prod., N. Amer. Strawberry Growers Assn. 6:47-49.

Eastburn, D.M. and W.D. Gubler. 1990. The detection and survival of Colletotrichum acutatum, a causal agent of strawberry anthracnose, in soil. Plant Dis. 74:161-163.

Ellis, M.A., L.V. Madden, K.M. Reynelds, and L.L. Wilson. 1987. Ohio fungicide evaluations for control of Botrytis gray mold of strawberry. Adv. Strawberry Prod., N. Amer. Strawberry Growers Assn. 6:50-52.

Fall, J. 1951. Studies on fungus parasites of strawberry leaves in Ontario. Can. J. Bot. 29:299-315.

Fulton, R.H. 1958. Studies on strawberry leaf spot in Michigan. Mich. Expt. Sta. Quart. Bul. 40:581-588.

George, S.W. and R.D. Milholland. 1987. Seasonal occurrence and recovery of Phytophthora fragariae in infected strawberry roots. HortScience 22:1254-1255.

George, S.W. and R.D. Milholland. 1986. Inoculation and evaluation of strawberry plants with Phytophthora fragariae. Plant Dis. 70:371-375.

Goode, P.M. 1956. Infection of strawberry roots by zoospores of Phytophthora fragariae. Trans. Brit. Mycol. Soc. 39:367-377.

Gooding, H.J., R.J. McNicol, and D. Macintyre. 1981. Methods of screening strawberries for resistance to Sphaerotheca macularis (Wall ex Frier) and Phytophthora cactorum (Leb. and Cohn). J. Hort. Sci. 56:239-245.

Gourley, C.O. 1974. A comparison of benomyl, thiophanate-methyl, and captan for control of strawberry fruit rot. Can. Plant Dis. Surv. 54:2730.

Grove, G.G., L.V. Madden, and M.A. Ellis. 1985a. Influence of temperature and wetness duration on sporulation of Phytophthara cactorum on infected strawberry fruit. Phytopathology 75:700-703.

Grove, G.G., L.V. Madden, and M.A. Ellis. 1985b. Splash dispersal of Phytophthora cactorum from infected strawberry fruit. Phytopathology 75:611-615.

Grove, G.G., M.A. Ellis, and L.V. Madden. 1985c. Leather rot of strawberry: A summary of research in Ohio. Adv. Strawberry Prod. 4:49.

Grove, G.G., M.A. Elilis, L.V. Madden, and A.F. Schmitthenner. 1985d. Overwinter survival of Phytophthora cactorum in infected strawberry fruit. Plant Dis. 69:514-515.

Grove, G.G., L.V. Madden, M.A. Ellis, and A.F. Schmitthenner. 1985e. Influence of temperature and wetness duration on infection of immature strawberry fruit by Phytophthora cactorum. Phytopathology 75:165-169.

Gubler, W.D. and D.M. Eastburn. 1988. Research progress report. Anthracnose in California. Adv. Strawberry Prod. 7:47-50.

Gubler, W.D., P. Gunnell, N.C. Welch, and R. Buchner. 1988. Strawberry diseases and control. Annu. Rpt. Strawberry Res., Calif. Strawberry Advisory Board. p. 12-36.

Gubler, W.D., L. Lile, N.C. Welch, and J.J. Marois. 1987. Epidemiology of strawberry leafspot in California. Annu. Rpt. Strawberry Res., Calif. Strawberry Advisory Board. p. 8-23.

Gubler, W.D., J.J. Marois, L. Lile, N. Welch, and R. Buchner. 1986. Epidemiology of strawberry leafspot in California. Annu. Rpt. Strawberry Res., Calif. Strawberry Advisory Board. p. 12-26.

Jeffers, W.F. 1957. Soil treatments for control of the red stele disease of strawberries. Plant Dis. Rptr. 41:415-418.

Jhooty, J.S. and W.E. McKeen. 1965. Studies on powdery mildew of strawberry caused by Sphaerotheca macularis. Phytopathology 55:281-285.

Jhooty, J.S. and W.E. McKeen. 1962. The perfect stage of Sphaerotheca macularis on strawberry plants. Plant Dis. Rptr. 46:218-219.

Johnson, H., A.H. Holland, A.O. Paulus, and S. Wilhelm. 1962. Soil fumigation found essential for maximum strawberry yields in southern California. Calif. Agr. 16:4-6.

Harris, C.M. and J.M. Harvey. 1973. Quality and decay of California strawberries stored in $\mathrm{CO}_{2}$ enriched atmospheres. Plant Dis. Rptr. 57:44-46.

Harvey, J.M., C.M. Harris, W.J. Tietjen, and T. Serio. 1980. Quality maintenance in truck shipments of California strawberries. U.S. Dept. Agr. Adv. Agr. Technol. W-12:1-13.

Hickman, C.J. and M.P. English. 1951. Factors influencing the development of red core in strawberries. Trans. Brit. Mycol. Soc. 34:223-236.

Horn, N.L. and R.G. Carver. 1963. A new crown rot of strawberry plants caused by Colletotrichum fragariae. Phytopathology 53:768-770.

Horn, N.L. 1961. Control of Botrytis rot of strawberries. Plant Dis. Rptr. 45:818-822.

Howard, C.M. and E.E. Albregts. 1982. Cleistothecia of Sphaerotheca macularis on strawberry plants in Florida. Plant Dis. 66:261-262.

Howard, C.M. and E.E. Albregts. 1973. Cassia obtusifolia, a possible reservoir for inoculum of Colletotrichum fragariae. Phytopathology 63:533534. 
Howard, C.M. 1972. A strawberry fruit rot casued by Colletottichum fragariae. Phytopathology 62:600-602.

Hunter, T., K.J. Brent, G.A. Carter, and J.A. Hutcheon. 1987. Effects of fungicide spray regimes on incidence of dicarboximide resistance in grey mould (Botrytis cinerea) on strawberry plants. Ann. Applied Biol. 110:515525.

Lile, L.S., W.D. Gubler, and J.J. Marois. 1990. Determination and control of the overwintering structure of Ramularia tulasne $i$ on strawberry in California. Plant Dis. (In press.)

Maas, J.L. 1984. Compendium of strawberry diseases. Amer. Phytopathol. Soc., St. Paul, Minn.

Maas, J.L. 1978. Screening for resistance to fruit rot in strawberries and red raspberries: A review. HortScience 13:423-426.

McIntyre, J.L. and G.S. Walton. 1981. Control of strawberry red stele by Phytophthora fragariea. Plant Dis. 65:835-836.

Nelson, P.E. 1957. Pathogenicity of Idriella lunat a on strawberry. Phytopathology 47:438-443.

Nemec, S. 1972. Temperature effects on Mycosphaerella fragariae and strawberry leaf spot development. Plant Dis. Rptr. 56:3345-348.

Nemec, S. 1971. Studies on resistance of strawberry varieties and selections to Mycosphaerella fragaria e in southern Illinois. Plant Dis. Rptr. 55:573576.

Paulus, A.O., V. Voth, J. Nelson, and H. Bowen. 1978. Control of Botrytis fruit rot of strawberry. Calif. Agr. 32:9

Paulus, A.O., V. Voth, R.S. Bringhurst, and N. Welch. 1973. Comparison of fungicides and methods of application for the control of Ramularia leafsoot of strawberry. Proc. 7th Brit. Insecticide and Fungicide Conf. $23471-476$.

Paulus, A.O., V. Voth, F. Shibuya, H. Bowen, and A.H. Holland. 1969. Fungicidal control of Botrytis fruit rot of strawberry. Calif. Agr. 23:15 16.

Pepin, H.S. and H.A. Daubeny. 1964. The relationships of English and American races of Phytophthora fragariae. Phytopathology 54:241.

Peries, O.S. 1962. Studies on strawberry mildew, caused by Sphaerotheca macularis (Wallr. ex Fries) Jaczewski: II. Host-parasite relationships on foliage on strawberry varieties. Ann. Applied Biol. 50:225-233.
Peries, O.S. 1962. Studies on strawberry mildew, caused by Sphaerotheca Biology 50:211-224.

Peterson, R.A. 1973. Fungicidal control of black spot (Colletotrichum acutatum) and grey mould (Botrytis cinerea) on strawberry fruit in southeastern Queensland. Queensland J. Agr. Animal Sci. 30:327-329.

Plakidas, A.G. 1948. Strains of Mycosphaerella fragariae. Phytopathology 38:988-992.

Powelson, R.L. 1960. Initiation of the strawberry fruit rot caused by Botrytis cinerea. Phytopathology 50:491-494.

Schroth, M.N., G.Y. Yuen, J.G. Hancock, and A.R. Weinhold. 1988. Alternatives to methyl bromide and chloropicrin for control of soilborne pathogens in strawberry production in California. Annu. Report Strawberry Res., Calif. Strawberry Advisory Board. p. 39-50.

Simpson, D.W. 1987. The inheritance of mildew resistance in everbearing and day-neutral strawberry seedlings. J. Hort. Sci. 62:329-334.

Smith, B.J. and L.L. Black. 1987. Resistance of strawberry plants to Colletotrichum fragaria e affected by environmental conditions. Plant Dis. 71:834-837.

Sommer, N.F., R.J. Fortlage, F.G. Mitchell, and E.C. Maxie. 1973. Reduction of postharvest losses of strawberry fruits from gray mold. J. Amer. Soc. Hort. Sci. 98:285-288.

Tanboon-Ek, P., G.G. Grove, and M.A. Ellis. 1983. Fungicide combinations for control of gray mold and leather rot of strawberry. Adv. Strawberry Prod. 2:9-11.

Welty, R.E. 1984. Blue lupine as a host for Colletotrichum trifoli $i$ from alfalfa and for $C$. fragariae from strawberry. Plant Dis. 68:142-144.

Wilhelm, S. 1984. The anthracnose disease of strawberry identified in California. Strawberry News Bul., Calif. Strawberry Advisory Board, Jan.

Wilhelm, S. and A.O. Paulus. 1980. How soil-fumigation benefits the California strawberry industry. Plant Dis. 64:264-269.

Wilhelm, S. and R.D. Nelson. 1980. Fungal diseases of the strawberry plant, p. 245-292. In: N.C. Childers (ed.). The strawberry. Cultivars to marketing. Horticultural Publications, Gainesville, Fla.

Wilhelm, S. 1961. Diseases of strawberry. A guide for the commercial grower. Univ. Calif. Agr. Expt. Sta. Circ. 494. 